\title{
輪軸の蛇行動の負の減衰に関する理論的考察
}

\section{A theoretical consideration to negative damping of hunting of wheelset}

\author{
Hideki SAKAI ${ }^{* 1}$ \\ ${ }^{* 1}$ Kindai Univ. Dept. of Robotics Engineering \\ 1 Umenobe, Takaya, Higashihiroshima-shi, Hiroshima 739-2116, Japan
}

Received: 20 February 2017; Revised: 22 May 2017; Accepted: 28 July 2017

\begin{abstract}
This paper considers ways to increase stability of wheelset hunting. The aim of this study is to introduce formulas which represent the damped natural frequency and its damping. This has been done by analytical and not by numerical calculation. These formulas are functions of mass, creep coefficient and other wheelset parameters. These formulas are obtained with a 2 degree of freedom wheelset model whose radius of gyration of yaw equals to a half of gauge and whose creep coefficient is isotropic, in the first part of this paper. In the second part, based on one of these formulas, ways to increase damping of wheelset hunting are discussed. First, it is shown that a longer wavelength of geometrical hunting is effective in reducing hunting at all vehicle speeds. Secondly, it is shown that at speeds slower than a certain speed, the damping is increased when the ratio of the wheelset mass to the creep coefficient is larger. Further, a symbolic formula for this boundary speed is obtained. Thirdly, if it is assumed that the wheelset mass is proportional to the square of the wheel radius, then at speeds higher than a certain speed, the damping is increased when the wheel radius is larger. Moreover a symbolic formula for this boundary speed is also obtained.
\end{abstract}

Keywords : Wheelset, Track, Hunting, Damping, Analytical solution, Formula

\section{1. 緒言}

鉄道車両に蛇行動が生じると，乗心地が悪化したり，場合によっては脱線の危険がある．蛇行動を生じにくく するために，輪軸を，台車枠に対してある特定の範囲の前後・左右の剛性で支持するが，それでも高速になると 蛇行動が生じる（日本機械学会編，2008）。蛇行動が生じる原因は，車輪踏面の勾配に起因する（弘津他，1984） ので，輪軸単体の蛇行動が生じにくいほど，車両系の蛇行動も生じにくい傾向があると思われる.

そこで本論文は，車両系の蛇行動の抑制のために，輪軸単体の蛇行動の低減法を考察する．輪軸の蛇行動のう ち, 幾何学的蛇行動は周知であるから，本論文では動的蛇行動として，輪軸単体の蛇行動を表す特性根の負の減 衰の減少法（すなわち減衰の増加法）を考察するものである. そのため，本論文では輪軸単体の蛇行動を以後， 単に蛇行動と記す．本論文の前半部では，各設計諸元による蛇行動の抑制に関する見通しを得るために，最適支 持剛性を表す文字式の関数（須田他，1986）にならって，蛇行動の減衰と波長を文字式で表す.この文字式を基 に，後半部では，減衰を増加させる方策を考察する.

\section{2. 輪軸の基本的性質}

\section{$2 \cdot 1$ モデル}

図 1 に示される輪軸のモデルを用いる．軌道は直線とし，軌道の中心線と車軸中心線との交点に原点 $\mathrm{o}$ を設定 する．軌道の方向に $x$ 軸を，枕木方向に $y$ 軸を，輪軸が左旋回する方向に正のアタック角 $\psi$ を定める.また輪軸

No.17-00064 [DOI:10.1299/transjsme.17-00064], J-STAGE Advance Publication date : 14 August, 2017

本論文は，第25回交通・物流部門大会 講演論文集(2016), No.1101の掲載内容に基づいた論文である.

*1 正員, 近畿大学工学部（下739-2116 広島県東広島市高屋うめの辺 1)

E-mail of corresponding author: sakai@hiro.kindai.ac.jp 
の $x$ 軸方向の速度を $V$ とする. なお $\psi$ は微小とし, $\sin \psi \fallingdotseq \tan \psi \doteqdot \psi$ および $\cos \psi \fallingdotseq 1$ が成り立つものとする.

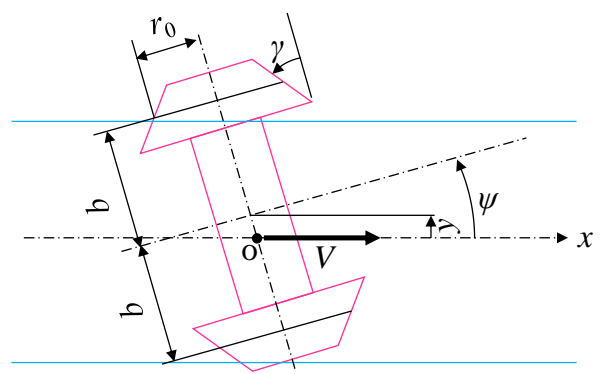

Fig. 1 Model of wheelset and track

次に, 輪軸の性質を表す記号として, 輪軸の質量を $m, y=0$ かつ $\psi=0$ のときの車輪の転がり回転半径を $r_{0}$, 踏 面勾配を $\gamma, \exists$ ヨ貫性半径を $i$, レルと車輪との接触点から軌道の中心までの距離を $b$, 前後クリープ係数を $\kappa_{11}$, 左右クリープ係数を $\kappa_{22}$ と記す.

このモデルの並進および回転についての運動方程式はそれぞれ次式で与えられる（日本機械学会編，2008）.

$$
\begin{aligned}
& m \ddot{y}=-\frac{2 \kappa_{22}}{V} \dot{y}+2 \kappa_{22} \psi \\
& m i^{2} \ddot{\psi}=-\frac{2 \kappa_{11} b^{2}}{V} \dot{\psi}-\frac{2 \kappa_{11} b \gamma}{r_{0}} y
\end{aligned}
$$

式(1)，(2)の初期条件を全て 0 としてラプラス変換をおこない，その特性方程式を求めると次のようになる.

$$
s^{4}+\frac{2\left(b^{2} \kappa_{11}+i^{2} \kappa_{22}\right)}{i^{2} m V} s^{3}+\frac{4 b^{2} \kappa_{11} \kappa_{22}}{i^{2} m^{2} V^{2}} s^{2}+\frac{4 b \kappa_{11} \kappa_{22} \gamma}{i^{2} m^{2} r_{0}}=0
$$

ここで $s$ はラプラス演算子である.式(3)に示されるように, 輪軸の蛇行動を表す特性方程式は $s$ の 4 次式である.

\section{$2 \cdot 2$ 特性方程式が $s$ の 3 次式以上の場合の解析法}

もしも特性方程式が $s$ の 2 次式であれば，固有振動数や減衰比が定式化できるので，蛇行動についての見通し を文字式で得ることができる. しかし式(3)は $s$ の 4 次式である.このような場合の解析手法は次の 3 つがあると 思われる.

1) 安定領域と不安定領域との臨界条件を定式化し，その式を考察する.

2) $s$ の 4 次式を， $s$ の 2 次式に近似して，固有振動数や減衰比を近似的に定式化する.

3) $s$ の 4 次式を因数分解して, 2 つの $s$ 次式に分解し, それぞれの固有振動数や減衰比を定式化する.

上記 1）の例に, 静止系から弾性的に支持されている場合の輪軸の蛇行動における臨界速度の考察（須田他, 1986）がある.この方法は本論文には適さないことを $2 \cdot 4$ 節で述べる.

上記 2）の一例が，次節で述べる幾何学的蛇行動（日本機械学会編，2008）である. 幾何学的蛇行動の場合, 減衰が 0 であるから，この方法も本論文には適さない.

そこで本論文が用いるのが上記 3）である．3）の例の既往研究として，自動車においてハンドルから手を放 寸場合の運動解析がある. 図 1 に示される輪軸を, 舵を中立位置で固定した場合の自動車とみな寸と, その自由

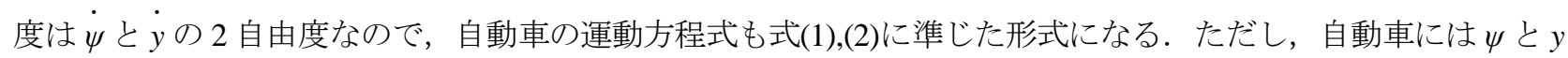
の項がないので, その特性方程式は $s$ の 2 次式である.この状態から, ハンドルから手を放した場合は, 操舵系 の自由度も加味されるので, その特性方程式は $s$ の 4 次式になる. この 4 次式が特殊な場合に厳密に因数分解さ れたり（酒井，2015a），一般的な場合に近似的に因数分解された（酒井，2015b）のが 3）の例である. 


\section{$2 \cdot 3$ 幾何学的蛇行動の固有振動数}

前節 2)の方法として，式(3)の記号解を求める従来の方法（日本機械学会編，2008）について述べる.まず,

$$
m=0
$$

と仮定する．式(3)の両辺に $m^{2}$ を乗じた上で，式(4)を代入することにより，式(3)は，

$$
\frac{b}{V^{2}} s^{2}+\frac{\gamma}{r_{0}}=0
$$

となる. したがって $m=0$ の場合の固有振動数を $\omega_{\mathrm{st}}$ と記すと

$$
\omega_{s t}=\sqrt{\frac{V^{2} \gamma}{b r_{0}}}
$$

となる.これが幾何学的蛇行動の固有振動数である. また， $\omega_{\mathrm{st}}$ を波長 $S_{1}$ で表すと，

$$
S_{1}=2 \pi \frac{V}{\omega_{s t}}=2 \pi \sqrt{\frac{b r_{0}}{\gamma}}
$$

となる（日本機械学会編，2008）。式(5)において減衰比は 0 だから，2）の方法は，本論文には適さないと思われ る.

\section{$2 \cdot 4$ 蛇行動の安定性}

2・2 節の 1)の方法として，本節では Huruwitz の安定判別（新，1996）を式(3)について行ない，安定と不安定 との臨界条件の考察を試みる.

式(3)が安定であるためには，次の 2 つの条件が同時に満たされる必要がある. 1 つ目の条件は，式(3)の $s$ の係 数の符号がすべて等しいことである. 式(3)の場合， $\gamma$ が正ならば，すべての係数が正になるので，この条件は満 たされている ( $\gamma$ が負ならば,この条件が満たされないので輪軸は常に不安定である).もう1つの条件は Huruwitz

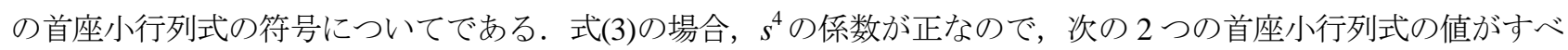
て正であることが安定性を満たすための 2 つ目の条件である.

$$
\begin{aligned}
& \left|\begin{array}{cc}
\frac{2\left(b^{2} \kappa_{11}+i^{2} \kappa_{22}\right)}{i^{2} m V} & 0 \\
1 & \frac{4 b^{2} \kappa_{11} \kappa_{22}}{i^{2} m^{2} V^{2}}
\end{array}\right|=\frac{2\left(b^{2} \kappa_{11}+i^{2} \kappa_{22}\right)}{i^{2} m V} \frac{4 b^{2} \kappa_{11} \kappa_{22}}{i^{2} m^{2} V^{2}}>0 \\
& \left|\begin{array}{ccc}
\frac{2\left(b^{2} \kappa_{11}+i^{2} \kappa_{22}\right)}{i^{2} m V} & 0 & 0 \\
1 & \frac{4 b^{2} \kappa_{11} \kappa_{22}}{i^{2} m^{2} V^{2}} & \frac{4 b \kappa_{11} \kappa_{22} \gamma}{i^{2} m^{2} r_{0}} \\
0 & \frac{2\left(b^{2} \kappa_{11}+i^{2} \kappa_{22}\right)}{i^{2} m V} & 0
\end{array}\right|=-\left[\frac{2\left(b^{2} \kappa_{11}+i^{2} \kappa_{22}\right)}{i^{2} m V}\right]^{2} \frac{4 b \kappa_{11} \kappa_{22} \gamma}{i^{2} m^{2} r_{0}}<0
\end{aligned}
$$


$\gamma$ が正ならば，式(9)は常に負であるから，2つ目の条件は常に満たされない.よって，輪軸は常に不安定である. そのため, 安定と不安定との臨界条件が存在しない. したがって，1）の方法も, 本論文には適さない.

\section{3. 蛇行動の減衰}

2・2 節の 1）の方法も 2）の方法も輪軸単体の蛇行動の減衰の考察には適さないと思われる．そこで本論文で は3）の方法として，式(3)を近似的に因数分解することによって，減衰を定式化する.

\section{$3 \cdot 1$ 仮定}

本論文では，式(3)を近似的に解くための仮定として，

$$
i=b
$$

かつ

$$
\kappa_{11}=\kappa_{22}=\kappa
$$

とする. 式(4)の仮定は用いない.

\section{$3 \cdot 2$ 特性方程式}

式(10)〜(11)を式(3)に代入すると

$$
s^{4}+2\left(\frac{2 \kappa}{m V}\right) s^{3}+\left(\frac{2 \kappa}{m V}\right)^{2} s^{2}+\frac{\gamma V^{2}}{r_{0} b}\left(\frac{2 \kappa}{m V}\right)^{2}=0
$$

となる。ここからしばらくは，表記を簡単にするために

$$
K_{m V} \equiv \frac{2 \kappa}{m V}
$$

と一時的におく．式(13)を式(12)に代入すると

$$
s^{4}+2 K_{m V} s^{3}+K_{m V}{ }^{2} s^{2}+\omega_{s t}{ }^{2} K_{m V}{ }^{2}=0
$$

となる．なお， $K_{m V}$ の次元は $\omega_{s t}$ のそれと同様，角速度と考えることができる.

\section{$3 \cdot 3$ 特性方程式の複二次式化とその解}

式(14)を数值的に解いた例を表 1 に示寸. 表 1 に示されるように，今回の諸元では，二組の根の虚部の絶対値 が互いに等しかった. そこで「二組の根の虚部の絶対值が互いに等しい」と仮定すると, 式(14)の二組の根は次 のように書ける.

$$
\begin{aligned}
& s=a \pm b j \\
& s=c \pm b j
\end{aligned}
$$


ここで， $a, b, c$ はそれぞれ実数であり, $j$ は虚数単位である. 式(15), (16)に記される 4 根を解に持つ変数 $s$ の方程式は，次のように書ける.

$$
\begin{aligned}
& (s-a-b j)(s-a+b j)(s-c-b j)(s-c+b j) \\
& =s^{4}-2(c+a) s^{3}+\left(a^{2}+2 b^{2}+c^{2}+4 c a\right) s^{2}-2(c+a)\left(b^{2}+c a\right) s+\left(a^{2}+b^{2}\right)\left(b^{2}+c^{2}\right)=0
\end{aligned}
$$

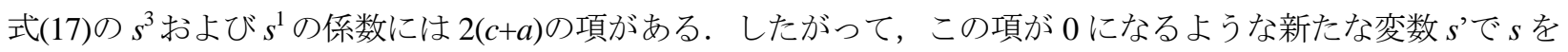

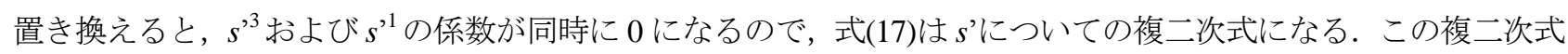
を二次方程式の解の公式を用いて解いた後で, $s$ に再変換することによって $s$ の記号解が求められるはずである.

そこで，この変数変換を行う．2 $(c+a)$ は $s$ の 4 根の実部の総和と等しいから，4根の実部の総和が 0 になるよう

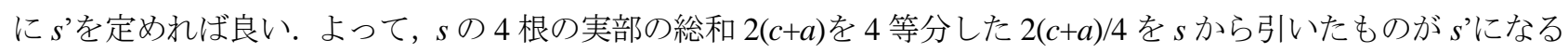
はずである.したがって 4 つの'は，式(15)，(16)から，

$$
\begin{aligned}
& s^{\prime} \equiv s-\frac{2(a+c)}{4}=\left[a-\frac{2(a+c)}{4}\right] \pm b j \\
& s^{\prime} \equiv s-\frac{2(a+c)}{4}=\left[c-\frac{2(a+c)}{4}\right] \pm b j
\end{aligned}
$$

と書ける．ここで-2(c+a)は，式(17)と式(14)のそれぞれの $s^{3}$ の係数どうしを比較することによって，

$$
-2(c+a)=2 K_{m V}
$$

である.この式を，式(18)または式(19)に代入すると

$$
s^{\prime}=s+\frac{2 K_{m V}}{4}
$$

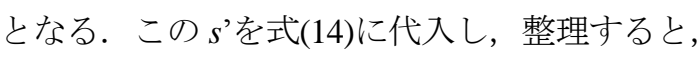

$$
s^{\prime 4}-\frac{K_{m V}{ }^{2}}{2} s^{\prime 2}+\left(\omega_{s t}{ }^{2} K_{m V}{ }^{2}+\frac{K_{m V}{ }^{2}}{16}\right)=0
$$

となる．式(22)は，前述のように $s^{2}$ についての二次方程式である（よって本節第一段落の仮定は正しい)，そこ で, 式(22)を, 二次方程式の解の公式を用いて $s^{2}$ について解くと,

$$
s^{\prime 2}=\left(\frac{K_{m V}}{2}\right)^{2}\left(1 \pm 4 \frac{\omega_{s t}}{K_{m V}} j\right)
$$

となる．この式の正負の平方根をとると 


$$
s^{\prime}= \pm \frac{K_{m V}}{2} \sqrt{1 \pm 4 \frac{\omega_{s t}}{K_{m V}} j}
$$

となる.この式の根号内は複素数であるから，s主複素数である。ただし，根号のために，実部と虚部とが分離 されていない.

Table 1 Numerical example of roots of eq. (12): These calculations are conducted with the following parameters: $m=1600[\mathrm{~kg}]$, $b=i=0.6[\mathrm{~m}], \kappa=(7.55+6.77) / 2[\mathrm{MN} / \mathrm{rad}], \gamma=1 / 20[\mathrm{rad}], r_{0}=0.43[\mathrm{~m}]$. Imaginary parts of two pairs of roots were consistent.

\begin{tabular}{|r|r|r|r|r|}
\hline & \multicolumn{2}{|c|}{ A pair of roots } & \multicolumn{2}{c|}{ The other pair of roots } \\
\hline$V[\mathrm{~m} / \mathrm{s}]$ & Real part [1/s] & Imaginary part [1/s] & Real part [1/s] & Imaginary part [1/s] \\
\hline 80 & -7.93873 & \pm 30.8410 & 119.814 & \pm 30.8410 \\
\hline 100 & -11.9170 & \pm 34.7647 & 101.417 & \pm 34.7647 \\
\hline 120 & -15.4763 & \pm 37.3334 & 90.0596 & \pm 37.3334 \\
\hline
\end{tabular}

\section{$3 \cdot 4$ 解の虚部と実部との分離}

この節では，二次方程式の解と係数の関係を利用して，式(24)の実部と虚部とを分離する. まず，式(24)の $s^{\prime}$ を次のように識別する.

$$
\begin{aligned}
& s_{1}^{\prime}=+\frac{K_{m V}}{2} \sqrt{1+4 \frac{\omega_{s t}}{K_{m V}} j} \\
& s_{2}^{\prime}=+\frac{K_{m V}}{2} \sqrt{1-4 \frac{\omega_{s t}}{K_{m V}} j} \\
& s_{3}^{\prime}=-\frac{K_{m V}}{2} \sqrt{1+4 \frac{\omega_{s t}}{K_{m V}} j} \\
& s_{4}^{\prime}=-\frac{K_{m V}}{2} \sqrt{1-4 \frac{\omega_{s t}}{K_{m V}} j}
\end{aligned}
$$

実部が共に正の $s_{1}{ }_{1}$ と $s_{2}{ }_{2}$ とが一組の共役複素根を，実部が共に負の $s_{3}{ }_{3}$ と $s_{4}{ }_{4}$ とがもう一組の共役複素根をそれ ぞれ構成する，ここで， $s^{\prime}{ }_{1}$ と $s_{2}{ }_{2}$ を根に持つ方程式は

$$
\left(s^{\prime}-s_{1}^{\prime}\right)\left(s^{\prime}-s_{2}^{\prime}\right)=0
$$

だから，これを展開すると

$$
s^{\prime 2}-\left(s_{1}^{\prime}+s_{2}^{\prime}\right) s^{\prime}+s_{1}^{\prime} s_{2}^{\prime}=0
$$

となる.ここで $s^{\prime}{ }_{1}$ と $s^{\prime}{ }_{2}$ の実部が共に正であることに注目すると，上式は 


$$
s^{\prime 2}-\sqrt{\left(s_{1}^{\prime}+s_{2}^{\prime}\right)^{2}} s^{\prime}+s_{1}^{\prime} s_{2}^{\prime}=0
$$

と変形できる．式(31)に式(25)，(26)を代入すると

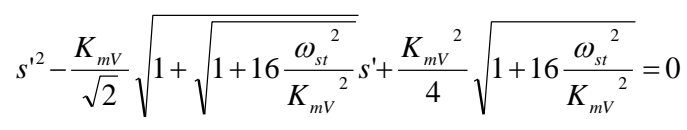

となる．したがって，二次方程式の解の公式より， $s^{\prime}$ は

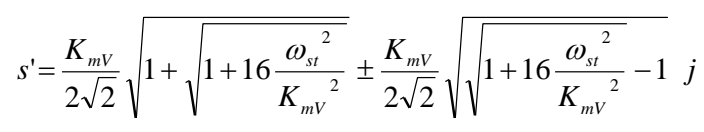

となる.この式のすべての根号内は正だから, 式(33)の右辺第 1 項は実数, 第 2 項は純虚数である. したがって, この式が，式(24)の実部と虚部とを分離した式である.

\section{$3 \cdot 5$ 特性根の定式化}

式(33)の $s^{\prime}$ ，式(21)を使って $s$ に戻すと

$$
s=\left(\frac{K_{m V}}{2 \sqrt{2}} \sqrt{1+\sqrt{1+16 \frac{\omega_{s t}{ }^{2}}{K_{m V}{ }^{2}}}}-\frac{K_{m V}}{2}\right) \pm\left(\frac{K_{m V}}{2 \sqrt{2}} \sqrt{\sqrt{1+16 \frac{\omega_{s t}{ }^{2}}{K_{m V}{ }^{2}}}-1}\right) j
$$

となる.この実部に-1 を乗じたものが，無減衰固有振動数 $\omega_{n}$ と減衰比 $と$ 積だから

$$
\zeta \omega_{n}=-\frac{K_{m V}}{2}\left(\sqrt{\frac{1+\sqrt{1+16 \frac{\omega_{s t}{ }^{2}}{K_{m V}{ }^{2}}}}{2}}-1\right)=-\frac{\kappa}{m V}\left(\sqrt{\frac{1+\sqrt{1+4 \frac{m^{2}}{\kappa^{2}} \frac{\gamma}{b r_{0}} V^{4}}}{2}}-1\right)<0
$$

となる.一般に $\zeta \omega_{n}$ が振動の減衰の速さを表すが，この式の值は負なので， $s_{1}{ }_{1}$ と $s_{2}{ }_{2}$ に由来する $\zeta \omega_{n}$ は発散の速さ を表す. また式(34)の虚部が, 減衰固有振動数 $\omega_{d}$ を表すから,

$$
\omega_{d}=\frac{K_{m V}}{2 \sqrt{2}} \sqrt{\sqrt{1+16 \frac{\omega_{s t}{ }^{2}}{K_{m V}{ }^{2}}}-1}=\frac{\kappa}{\sqrt{2} m V} \sqrt{\sqrt{1+4 \frac{m^{2}}{\kappa^{2}} \frac{\gamma}{b r_{0}} V^{4}}-1}
$$

となる. 式(36)に示される $\omega_{d}$ を波長 $S_{1}$ に換算すると

$$
S_{1}=2 \pi \frac{V}{\omega_{d}}=2 \pi \frac{\sqrt{2} m V^{2}}{k \sqrt{\sqrt{1+4 \frac{m^{2}}{\kappa^{2}} \frac{\gamma}{b r_{0}} V^{4}}-1}}
$$


となる.

一方， $s_{3}{ }_{3}$ と $s_{4}^{\prime}$ についても， $s_{3}^{\prime}$ と $s_{4}{ }_{4}$ の実部が共に負であることに留意して，式(32)〜(36) と同様に特性根の実 部と虚部を求めると，それぞれ

$$
\begin{gathered}
\zeta \omega_{n}=\frac{K_{m V}}{2}\left(\sqrt{\frac{1+\sqrt{1+16 \frac{\omega_{s t}{ }^{2}}{K_{m V}{ }^{2}}}}{2}}+1\right)=\frac{\kappa}{m V}\left(\sqrt{\frac{1+\sqrt{1+4 \frac{m^{2}}{\kappa^{2}} \frac{\gamma}{b r_{0}} V^{4}}}{2}}+1\right)>0 \\
\omega_{d}=\frac{K_{m V}}{2 \sqrt{2}} \sqrt{\sqrt{1+16 \frac{\omega_{s t}{ }^{2}}{K_{m V}{ }^{2}}}-1}=\frac{\kappa}{\sqrt{2} m V} \sqrt{\sqrt{1+4 \frac{m^{2}}{\kappa^{2}} \frac{\gamma}{b r_{0}} V^{4}}-1}
\end{gathered}
$$

となる．式(38)の值は正だから， $s_{3}^{\prime}$ と $s_{4}^{\prime}$ に由来する根は安定根である．また式(39)は式(36)と同值である．した がって，式(35),(36),(38)が，式(10),(11)の仮定下の特性根の厳密解の記号解である.

\section{4. 記号解の検証}

\section{$4 \cdot 1$ 近似精度}

道辻の資料（2015）に記載されている值を用いた場合の数值解と， $\kappa=\left(\kappa_{11}+\kappa_{22}\right) / 2$ として式(35),(36),(38)を用いて 計算した結果との比較を図 2 に示寸．この数值は図 2 のキャプションに記載してある. また， $i$ の值が不明だっ たので $i=b$ とした. 以後, この数值を基準諸元と記す.

両者の比較から，基準諸元においては，式(11)の仮定の影響は顕著でないように見える，なお，以後本論文で は，不安定根を表す式(35),(36)だけについて扱う。そのため，「負の減衰の減少」を単に「減衰の増加」と以後記 す.

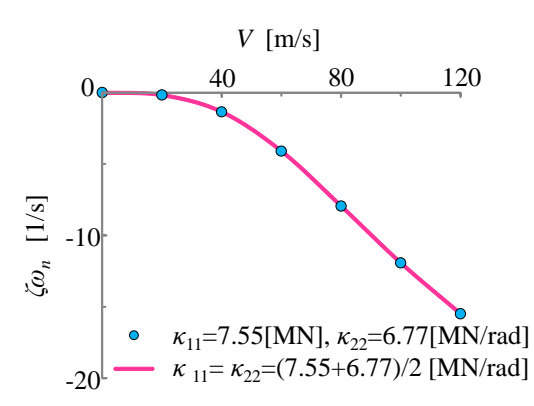

(A) Real part of unstable root

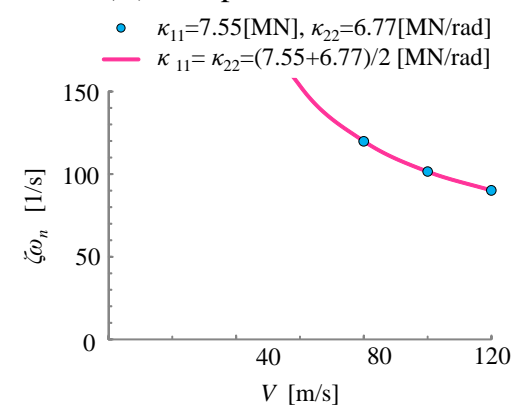

(C) Real part of stable root

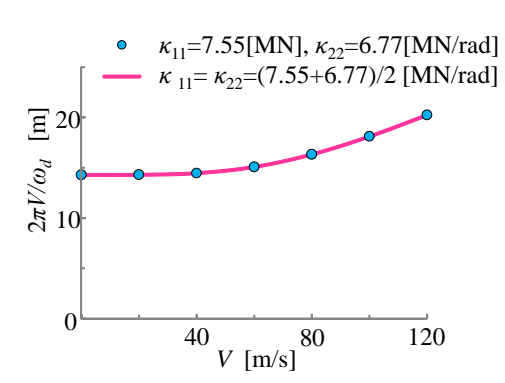

(B) Imaginary part of unstable root

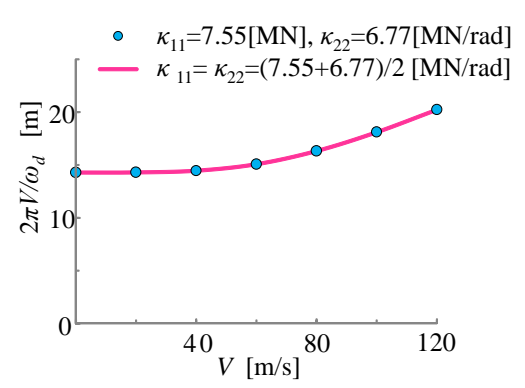

(D) Imaginary part of stable root

Fig. 2 Example of calculation; These calculations are conducted with the following parameters: $m=1600[\mathrm{~kg}], b=0.6[\mathrm{~m}]$, $\kappa_{11}=7.55[\mathrm{MN}], \kappa_{22}=6.77[\mathrm{MN} / \mathrm{rad}], \gamma=1 / 20[\mathrm{rad}], r_{0}=0.43[\mathrm{~m}]$. In addition, $i=b$. These lines were calculated with eq. (35) and (36). These dots are numerical solutions of eq. (3). From these figures, it is thought that eq. (35),(36) and (38) express fundamentals of the hunting of wheelset. 


\section{$4 \cdot 2$ クリープ係数の前後と左右との比の近似誤差}

基準諸元では $\kappa_{22} / \kappa_{11}=0.88$ であるが， $\kappa_{22} / \kappa_{11}$ の下限值は 0.8 との指摘がある（振動工学ハンドブック編集委員会 編，1991).そこで，この下限值を想定して，図 2 の諸元において $\kappa_{11}+\kappa_{22}$ の值を一定のまま, $\kappa_{22} / \kappa_{11}=0.8$ として計 算した結果を図 3 に示寸．この場合も，式 (11)の仮定の影響は顕著でないように思われる.

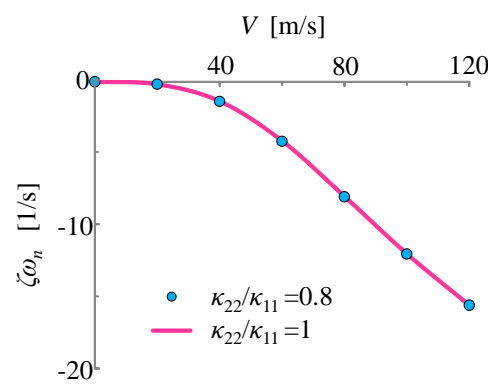

(A) Real part of unstable root

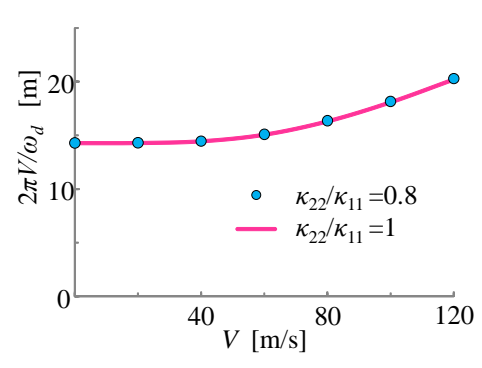

(B) Imaginary part of unstable root

Fig. 3 Error due to the ratio of longitudinal creep ratio $\kappa_{11}$ to that of lateral $\kappa_{22}$ : This calculation is conducted with the values described in fig.2 except $\kappa_{11}$ and $\kappa_{22}$. In this calculation, $\kappa_{11}+\kappa_{22}=7.55+6.77[\mathrm{MN}]$ is assumed. These lines were calculated with eq. (35) and (36). These dots are numerical solutions of eq. (3). In case of $\kappa_{22} / \kappa_{11}=0.8$, the approximation as $\kappa_{22} / \kappa_{11}=1$ dose not yield any significant difference.

\section{$4 \cdot 3$ 慣性半径の近似誤差}

輪軸のうち，車輪分のヨ一慣性半径は $b$ である。一方，車軸を長さ $2 b$ の一様な棒と見な寸と，その慣性半径は $b / 3^{1 / 2}$ である (小野寺, 矢野, 2014). したがって, 輪軸全体の慣性半径は $b$ よりも小さいものと思われる. そこで図 2 の計 算諸元から $i / b$ を 0.95 に変更して, 数值計算で求めた值と, 式(35),(36)による值との比較を図 4 に示寸. 図 4 に示され るように, 蛇行動の基本的性質は式(35),(36)によって考察できると思われる. なお， $\kappa_{22} / \kappa_{11}<1$ による誤差とi/b<1 を無視 した誤差とは，互いに打消しあう側に生じた。

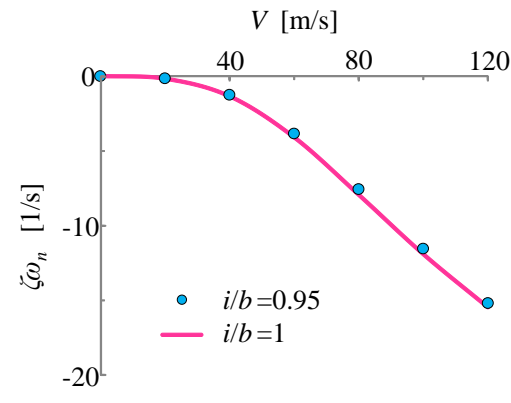

(A) Real part of unstable root

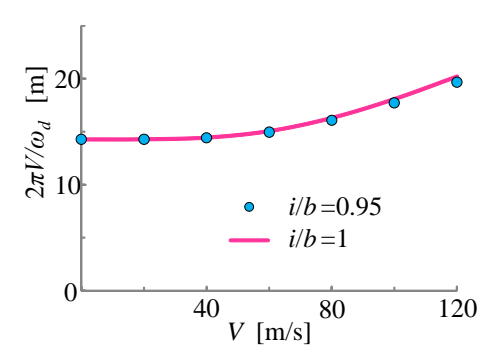

(B) Imaginary part of unstable root

Fig. 4 Error due to the radius of gyration $i$ : This calculation is conducted with the values described in fig.2 except $i$. Thus, in this calculation, $b$ is constant. These lines were calculated with eq. (35) and (36). These dots are numerical solutions of eq. (3). Even in the approximation as $i / b=1$, the fundamental properties of $\zeta \omega_{n}$ and $\omega_{d}$ appear to be represented by equations (35) and (36), respectively.

\section{$4 \cdot 4$ 記号解の成立範囲}

以上の結果，式(35),(36),(38)は，少なくとも $1 \geqq \kappa_{22} / \kappa_{11} \geqq 0.8$ かつ $1 \geqq i / b \geqq 0.95$ の範囲で，蛇行動の基本的性質を 表すものと思われる.

\section{5. 考察}

\section{$5 \cdot 1$ 特性根の大域的性質}

本節では, $V$ に対する $\zeta \omega_{n}$ の大域的性質を考察する. まず, $V \fallingdotseq 0$ 付近の基本的性質を考察するために，式(35) をVについてマクローリン展開すると 


$$
\zeta \omega_{n}=-\frac{1}{2}\left(\frac{m}{k}\right)\left(\frac{\gamma}{b r_{0}}\right) V^{3}+O(V)^{7}
$$

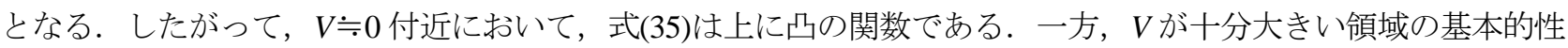
質を考察するために, $V \rightarrow \infty$ とすると

$$
\operatorname{Lim}_{V \rightarrow \infty} \zeta \omega_{n}=-\sqrt[4]{\left(\frac{\kappa}{m}\right)^{2}\left(\frac{\gamma}{b r_{0}}\right)}
$$

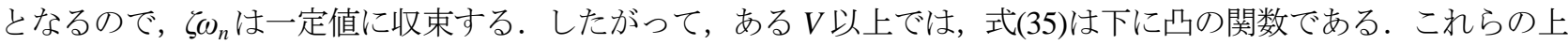
に凸と下に凸との影響が互いに打ち消し合うのが，図 2(A) 4(A)における $V \fallingdotseq 85[\mathrm{~m} / \mathrm{s}]$ 付近の変曲点であると思わ れる.

次に, $V$ に対する $S_{1}$ の大域的性質を考察する. $S_{1}$ は, $V \fallingdotseq 0$ の付近では

$$
S_{1}=2 \pi \frac{V}{\omega_{d}} \approx 2 \pi\left[1+\frac{1}{2}\left(\frac{m}{k}\right)^{2} V^{4}\right] \sqrt{\frac{b r_{0}}{\gamma}}
$$

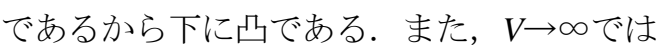

$$
\operatorname{Lim}_{V \rightarrow \infty} \omega_{d}=\sqrt[4]{\left(\frac{\kappa}{m}\right)^{2} \frac{\gamma}{b r_{0}}}
$$

となるので上に凸になる．図2(B)〜4(B)は，下に凸なので，式(42)の領域に対応するものと思われる.

式(40)〜(43)は, $V$ を除くと, $k / m$ と $\gamma / b r_{0}$ との二つの項によって構成されている. そこで, 次節以降では, これ らの項に注目することによって，減衰の増加法を考察する.

\section{$5 \cdot 2$ 幾何学的蛇行動の長波長化による減衰の増加法}

前節最終段落で指摘された特性根を構成する 2 項のうちの一つが $\gamma / b r_{0}$ である. $\gamma / b r_{0}$ の逆数の平方根に $2 \pi$ を乗 じたものが，幾何学的蛇行動の波長である．そこで本節では，幾何学的蛇行動の波長に注目する．静止系から弾 性支持された輪軸が不安定になる臨界速度は, 輪軸単体の幾何学的蛇行動波長に比例する (日本機械学会編, 2008)。 一方, 式(35)から, $\gamma / b r_{0}$ が小さいほど $\zeta \omega_{n}$ は大きくなる. したがって, 幾何学的蛇行動の長波長化による臨界速度 の増加は， $\gamma / b r_{0}$ の低減による $\zeta \omega_{n}$ の増加に起因寸ると思われる。 そこで, これを確認したものが, 図 5 である. ここでは， $\gamma$ を減少させることによって，図 5(B)に示されるように，蛇行動の波長を増加させた．その結果，図 5(A)から，予想どおり，減衰が増加したことが分かる.

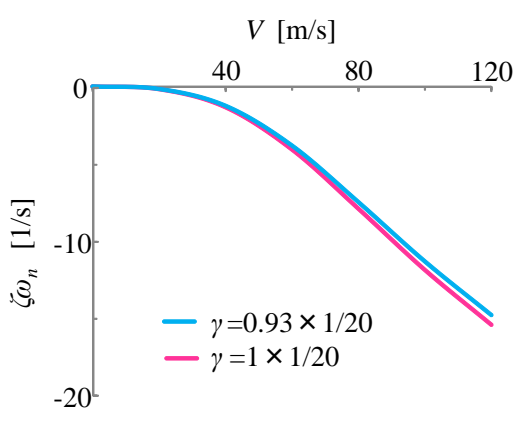

(A) Real part of unstable root

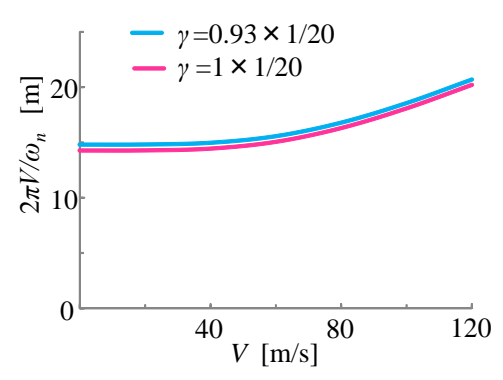

(B) Imaginary part of unstable root

Fig. 5 Influence of the gradient of wheel tread $\gamma$ : This calculation is conducted with the values described in fig. 2 except $\gamma$. When the gradient of wheel tread $\gamma$ decrease, $\zeta \omega_{n}$ increases at this $V$. 


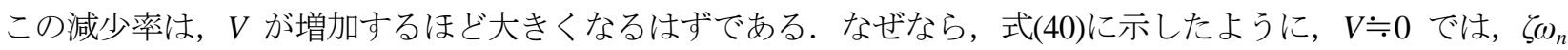

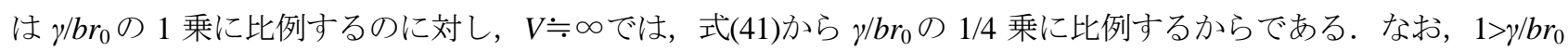
ならば, $\left(\gamma / b r_{0}\right)^{1 / 4}>\left(\gamma / b r_{0}\right)^{1}$ である.

以上のように, 幾何学的蛇行動の長波長化による蛇行動の抑制は, 弾性支持された輪軸だけでなく, 輪軸単体 においても有効である，ただし両者の因果関係としては，輪軸単体の蛇行動の減衰が増加した結果として，弾性 支持された輪軸の蛇行動の臨界速度が増加寸るものと思われる.

\section{$5 \cdot 3$ 車輪質量に注目した減衰の増加法}

本節では輪軸の軽量化等による減衰の増加を検討する. $m$ が変化すると輪重が変化し， $\kappa$ も変化する. ここで $\kappa$ は輪重 $2 / 3$ 乗に比例する（横瀬，1971）と仮定する．そこで

$$
\kappa=q(m+M)^{\frac{2}{3}}
$$

と記す.ここで $M$ は, $(M+m) g$ が輪重になるように定義される量である $(g$ は重力加速度). すなわち 2 軸台車の場 合の $M$ は，輪軸を除いた車両質量の $1 / 4$ である（連接車を除く）。また $q$ は比例定数であり，基準諸元と整合す るように設定される.

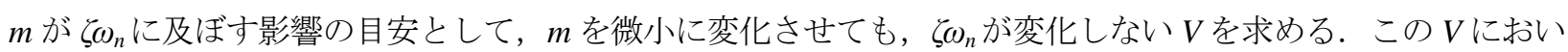
$\tau$

$$
\frac{\partial \zeta \omega_{n}}{\partial m}=0
$$

が成り立つ必要がある。この $V$ は，式(44)を考慮した場合，解析的には求まらない．式(44)に記される輪重の $2 / 3$ 乗は，輪重の 1 乗と輪重の 0 乗との間にある．そこで両者の場合を定式化する．まず前者の場合として

$$
\kappa=q^{\prime}(m+M)
$$

と仮定する．ここで $q^{\prime}$ は定数であり，基準諸元と整合するように設定される．上式を式(35)に代入したものをさ らに式(45)に代入し，それを満たす $V$ を求めると

$$
V=\sqrt[4]{(2+\sqrt{5})\left(1+\frac{M}{m}\right) \frac{b r_{0}}{\gamma}\left(\frac{\kappa}{m}\right)^{2}}
$$

となる. したがって $M / m$ が小さいほど，すなわち $m$ が大きいほどこの $V$ が低速側に移動する. 一方，輪重の 0 乗，すなわち

$$
V=\frac{\sqrt{2}}{5} \sqrt[4]{(2+\sqrt{5}) \frac{b r_{0}}{\gamma}\left(\frac{\kappa}{m}\right)^{2}}
$$

となる．この場合も， $m$ が大きいほどこの $V$ が低速側に移動する．両者の結果から， $\kappa$ が輪重の $2 / 3$ 乗の場合も

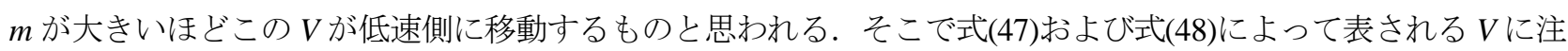
目する.

式(47)，(48)に基準諸元を代入すると，どちらもV=144.6[m/s]になった. そこで，この $V$ よりも低速側での $\zeta \omega_{n}$ の増加を狙って, 輪軸の軽量化によって $\kappa / m$ を増加させた場合の計算結果を図 6 に示寸. 予想通り, 少なくとも $0 \leqq V \leqq 120[\mathrm{~m} / \mathrm{s}]$ の範囲において $\zeta \omega_{n}$ が増加した。 


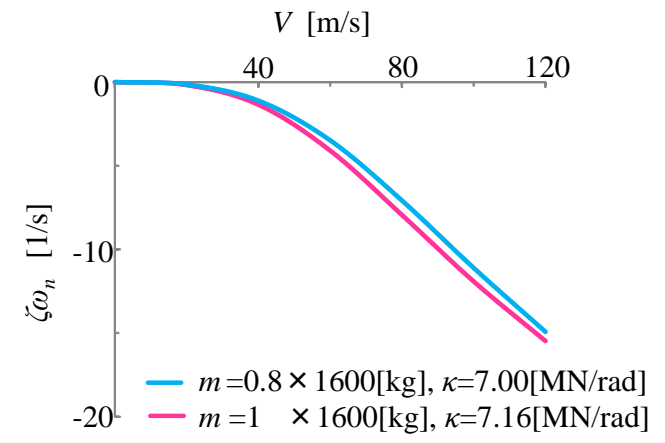

(A) Real part of unstable root

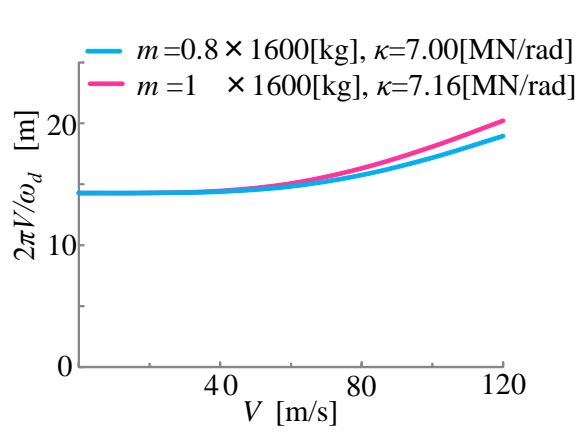

(B) Imaginary part of unstable root

Fig. 6 Influence of the mass of wheelset $m$ : This calculation was conducted with the values described in fig.2 except $m$ and $\kappa . \kappa$ is determined by eq. (44). Further $m$ is assumed $4150[\mathrm{~kg}]$. Reduction of $m$ increases $\zeta \omega_{n}$.

\section{$5 \cdot 4$ 車輪の大径化による減衰の増加法}

5.2 節では, 幾何学的蛇行動の長波長化によって $\zeta \omega_{n}$ を増加できることを示した. 長波長化を $r_{0}$ の増加によって も図った場合, $m$ も増加する可能性がある. $m$ が変化すると, 前節で述べたように $\zeta \omega_{n}$ も変化する. そこで本節 では， $r_{0}$ が増加すると $m$ も増加すると仮定したときの $r_{0}$ が $\zeta \omega_{n}$ に及ぼす影響を考察する.

簡単のため $m$ は，枕木方向から見た車輪面積に比例すると仮定し，

$$
m=p r_{0}^{2}
$$

とおく．ここで $p$ は比例定数であり，基準諸元における $r_{0}$ と $m$ との関係を満足するように設定される.

次に $r_{0}$ が $\zeta \omega_{n}$ に及ぼす影響の目安として, $r_{0}$ を微小に変化させても, $\zeta \omega_{n}$ が変化しない $V$ を求める. ただし式(44) を適用寸ると記号解を求衫ことは困難なので，この $V$ を求めるときは， $m$ が変化しても， $\kappa$ は一定とする. そ こで，式(49)だけを式(35)に代入すると

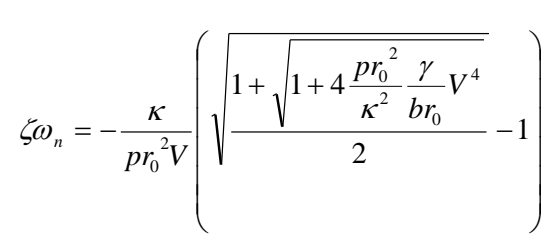

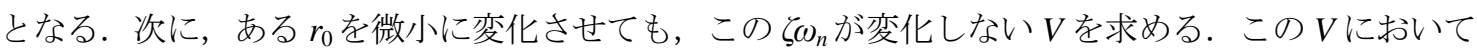

$$
\frac{\partial \zeta \omega_{n}}{\partial r_{0}}=0
$$

が成り立つ. そこで，式(50),(51)を解いてこの $V$ を求めると

$$
V=\frac{\sqrt{2}}{5} \sqrt[4]{(47+9 \sqrt{89})\left(\frac{\kappa}{p r_{0}^{2}}\right)^{2} \frac{b}{r_{0}}}
$$

となる. 
この $V$ よりも低速側では， $r_{0}$ が小さい方が，高速側では $r_{0}$ が大きい方が，減衰が増加する．したがって，この $V$ を， $r_{0}$ が $\zeta \omega_{n}$ に及ぼす影響を考察する上での指標とする.

この $V$ は，基準諸元では $V=96.6[\mathrm{~m} / \mathrm{s}]$ あっった。そこで，この $V$ よりも高速側における減衰の増加を狙って， $r_{0}$ を基準諸元の 1.2 倍したときの影響を図 7 に示す. 図 7 の計算において， $\kappa$ の計算には式(44)を用いた. 図 7 にお いて，目安である $V=96.6[\mathrm{~m} / \mathrm{s}]$ よりも低い $V \fallingdotseq 87[\mathrm{~m} / \mathrm{s}]$ の高速側で $\zeta \omega_{n}$ が増加した。 したがって本諸元における車輪 の大径化による蛇行の低減策は，質量およびクリープ係数を考慮しても，有効であった.

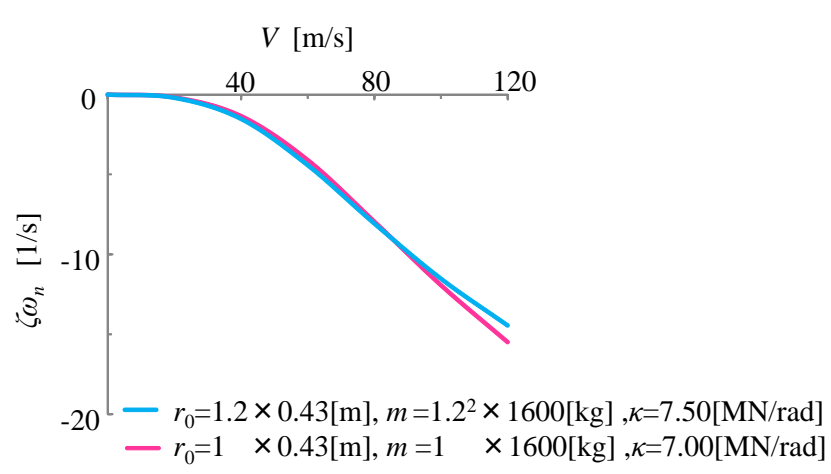

(A) Real part of unstable root

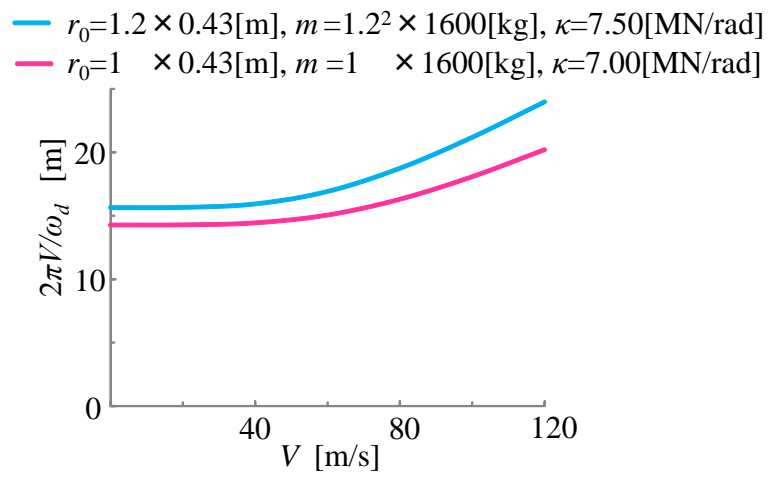

(B) Imaginary part of unstable root

Fig.7 Influence of the radius of wheel $r_{0}$ related mass of the wheelset $m$ ( $\kappa$ is defined as a function of $m$ ): This calculation is conducted with the values described in fig.2 except $r_{0}$ and $m$ and $\kappa . \kappa$ is determined by eq. (44). An increase in $r_{0}$ increased $\zeta \omega_{n}$ at $V>87[\mathrm{~m} / \mathrm{s}]$.

\section{6. 結 言}

慣性半径が軌間の半分に等しくかつ前後と左右のクリープ係数が等しいとの仮定をおいたときの輪軸の蛇行動 の特性根の厳密解を定式化した.

特性根は次の 2 つ值によって変化する. 1 つはクリープ係数を輪軸の質量と車速との積で除したものである. したがって，車速が一定な場合は，「(クリープ係数）／(輪軸の質量)」の值に左右される．もう1つは， 幾何学的蛇行動の固有振動数である.

輪軸の質量が増加すると輪重が増加するので，クリープ係数も増加する．そこでクリープ係数が輪重の $2 / 3$ 乗 に比例するとした場合の「(クリープ係数）／(輪軸の質量)」が減衰比に及ぼす影響を文字式で考察し た．その結果，輪軸の質量を軽量化するほど負の減衰が減少（すなわち減衰が増加する）ことを指摘し

た．ただし，今回の計算諸元では車速 $145[\mathrm{~m} / \mathrm{s}]$ 以上では，軽量化するほど減衰が低下寸る.

車輪の転がり半径を増加させると, 幾何学的蛇行動の固有振動数が減少するほか, 輪軸の質量が増加し, その ためクリープ係数も増加するので，「(クリープ係数）／(輪軸の質量)」も変化する．そこでこの影響を 加味したときの転がり半径が減衰に及ぼす影響を調査し, 車速 $120[\mathrm{~m} / \mathrm{s}]$ では大径化するほど減衰が増加す ることを指摘した. ただしある車速よりも低速側では小径化するほど減衰が増加する.この臨界車速は, 今回の計算諸元では $87[\mathrm{~m} / \mathrm{s}]$ であった.

本研究で定式化した減衰および固有振動数の式の近似精度を考察した. 少なくとも「(慣性半径) / (軌間の半 分)」が $0.95 \sim 1$ かつ「(左右クリープ係数）／（前後クリープ係数）」が $0.8 \sim 1$ の範囲では近似誤差が無

視できると考えられる.

本研究は輪軸単体についての考察であったので，今後は台車レベルでの文字式による考察に発展させていきた いと考えている. 
謝辞

本研究にあたり，日本機械学会交通・物流部門鉄道技術委員会の委員の皆様にご指導を頂きました. ここに感 謝の意を表します.

\section{文献}

弘津哲二，森田雄三，岩崎文雄，石田周二，鉄道車両のだ行動のシミュレーション（第 1 報，各部の遊間を考慮

した力学モデルとその過渡現象)，日本機械学会論文集 C 編，Vol.50, No.450 (1984),pp.297-306.

道辻洋平，鉄道車両の運動，若手技術者のための「鉄道のダイナミクス」，No.15-76 (2015), pp.3-13.

小野寺忠，矢野澄雄，演習で学ぶ機械力学，森北出版 (2014), p.62.

新誠一，制御理論の基礎，昭晃堂 (1996), pp.42-43.

酒井英樹, フォースコントロールにおいて不安定領域を有する車両の動的挙動についての基礎的研究, 日本機械 学会論文集, Vol.81, No.823 (2015a), DOI: 10.1299/transjsme.14-00384.

酒井英樹, フォースコントロール下の固有振動数についての一考察, 日本機械学会論文集, Vol.81, No.824 (2015b),

DOI: 10.1299/transjsme.14-00663.

振動工学ハンドブック編集委員会編，振動工学ハンドブック，養賢堂 (1991), pp.1160-1163.

須田義大, 藤岡健彦, 井口雅一, 高速走行性能からみた軸箱支持剛性の最適設計, 日本機械学会論文 C 編, Vol.52,

No.475 (1986), pp.1003-1010.

日本機械学会編，車両システムのダイナミックスと制御，養賢堂 (2008), pp.116-127.

横瀬景司，車輪とレールのすべり現象について，日本機械学会論文集，Vol.37, No.304 (1971), pp.2407-2422.

\section{References}

Hirotsu, T., Morita, Y., Iwasaki, H. and Ishida, S., Tetsudo sharyou no dakoudou no simyurasyon (Daiippou, Kakubu no yuukann wo kouryo shita rikigakumoderu to sono katogennsho), Transactions of the Japan Society of Mechanical Engineers, Series C, Vol.50, No.450 (1984), pp.297-306 (in Japanese).

Michitsuji, Y., Tetstudou sharyou no undou, Wakate gijyutsusha notameno "Tetsudou sharyou no dainamikusu", JSME No.15-76 (2015), pp.3-13 (in Japanese).

Onodera, T. and Yano, S., Enshuu de manabu kikairikigaku, morikita (2014), p.62 (in Japanese).

Shin, S., Basis of control theory, Shokodo (1996), pp.42-43 (in Japanese).

Sakai, H., A fundamental study of dynamic behavior of vehicles with unstable region under force control, Transactions of the JSME (in Japanese), Vol.81, No.823 (2015a), DOI: 10.1299/transjsme.14-00384.

Sakai, H., A consideration to natural frequencies under force control, Transactions of the JSME (in Japanese), Vol.81, No.824 (2015b), DOI: 10.1299/transjsme.14-00663.

Suda, Y., Fujioka, T., and Iguchi M., Optimal design of primary stiffness form viewpoint of high speed performance for rail vehicles, Transactions of the Japan Society of Mechanical Engineers, Series C, Vol.52, No.475 (1986), pp.1003-1010(in Japanese).

Shidoukougakuhandbukkuhenshuiinnkaihenn, Sindoukougakuhandbukku, Yokendo (1991), pp.1160-1163.

The Japan Society of Mechanical Engineers ed., Sharyousisutemu no dainamikkusu to seigyo, Yokendo (2008), pp.116-127(in Japanese).

Yokose, K., Sharin to reru no suberi gensho nituite, Transactions of the Japan Society of Mechanical Engineers, Vol.37, No.304 (1971), pp.2407-2422 (in Japanese). 